\title{
Main Concerns in the Romanian Medical System - a Doctor's Perspective Over the Last 3 Years
}

Andrei MARIN', Teodor Cristian BLIDARU², Georgiana Gabriela MARIN³

\begin{abstract}
All medical societies struggle with different problems. While in developed countries, the main complaint of the doctors is related to overwork due to insufficient personnel, the Romania doctors have many other reasons for being dissatisfied with the activities they perform. The aim of this article is to compare how the doctors' problems have evolved over the last 3 years, which problems have been solved and which still need to be confronted. In order to do this, an analysis of 2 set of surveys will be performed, one conducted in 2016 by the Multidisciplinary Society of Medical Residents (SMMR) and one conducted in 2019 by the Romanian Federation of Medical Students' Associations. Both societies - one of the medical residents, the other representing the medical students, have shown a great interest in revealing the problems of the Romanian medical health care system, which has a great impact both on patients as well as medical personnel dynamics.
\end{abstract}

Keywords: medical organizations, health system, young doctors, health workforce.

\section{Rezumat}

Toate societățile medicale se luptă cu diferite probleme. Dacă în țările dezvoltate, principala nemulțumire a medicilor este legată de suprasolicitarea din cauza unui personal insuficient, medicii români au mai multe motive de a fi nemulțumiți de activitatea medicală pe care o desfășoară. Scopul acestui studiu este acela de a compara cum au evoluat problemele doctorilor în ultimii 3 ani, ce probleme au fost rezolvate și care constituie încă un subiect de interes. Pentru a face această evaluare, au fost analizate două sondaje, unul realizat în 2016 de către Societatea Multidisciplinară a Medicilor Rezidenți (SMMR), celălalt realizat în 2019 de către Federația Asociațiilor Studenților în Medicină din România (FASMR). Ambele asociații - una a medicilor rezidenți, cealaltă reprezentând colectivul studențesc, au arătat un adevărat interes în evidențierea problemelor din sistemul medical românesc, având impact atât asupra pacienților, cât și asupra dinamicii personalului medical.

Cuvinte cheie: societăți medicale, studiu, probleme medicale, sistem de îngrijire medicală.

\footnotetext{
${ }^{1}$ Department of Plastic Surgery, „Bagdasar Arseni” Emergency Hospital, Bucharest, Romania

${ }^{2}$ University of Medicine and Pharmacy, Carol Davila, Bucharest

${ }^{3}$ Department of Cardiology, „Prof. Dr. C.C. Iliescu" Emergency
}

Corresponding author.

Andrei MARIN, Department of Plastic Surgery, "Bagdasar Arseni” Emergency Hospital, Bucharest, Romania.

E-mail: marin_dpt@yahoo.com 


\section{INTRODUCTION}

Romania is one of the countries that prepares many medical students to become great doctors. The number of students in all medical universities has increased significantly over the past 10 years and consequently the number of places for the residency training increased. Only in Bucharest, this number increased from 600 students in 2007 to over 1400 students in $2019^{1}$. Despite this significant increase, the country still has problems when it comes to national coverage (having hospitals which are understaffed and some hospitals having been closed altogether due to lack of medical personnel).

\section{MATERIALS AND METHOD}

In order to understand this phenomenon, one must have a look at the main issues that cause dissatisfaction among doctors, to know which the main reasons for migration are. Only a good understanding of these problems could bring out solutions that could eventually stop this migration process.

Among the doctors who choose a different country to practice medicine, young doctors (residents and specialists) have a higher percentage ${ }^{2}$. It is therefore reasonable to survey these doctors to find out what motivates them to start over after having completed more than 18 years of studies in the Romanian system.

One much debated problem among residents is that of the on call shifts. In the first 2 years of residency, this extra time spent in hospital was compulsory for many clinics and but it was an unpaid activity. During these 2 years, the residents are considered to gain experience on how to handle emergencies and therefore the learning process remained unpaid. Furthermore, there was no legal form in which residents in the first 2 years could be paid for their work during the on call shifts.

Due to this situation, in some hospitals this „voluntary" activity extended beyond the 2 year of residency. In some clinics, residents perform on call duties during the entire residency period. Although they didn't even have a voluntary contract for this activity, the residents were compelled to do these on call duties all over the country, much to their dissatisfaction.

In an attempt to realize how big this phenomenon was, a survey among the residents nationwide was devised in 2016, which was answered by more than 700 residents. The Multidisciplinary Society for Medical Residents (SMMR) made these pieces of information then public and sent them to the Ministry of Health ${ }^{3}$.

\section{RESULTS}

The first question regarded the number of on call duties performed by residents and the majority of the responders estimated this number between 3 and 4, while the second most chosen option was 5-6 on call duties. (The pie chart below depicts the exact percentage as well as the overall number responders).

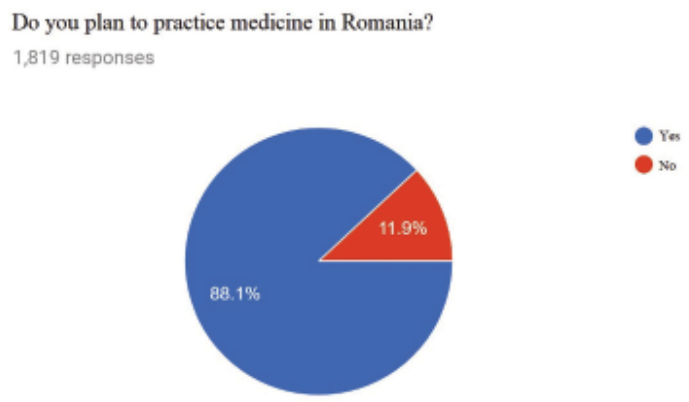

The second addressed questioned was if the on-call duties are paid or not. The pie chart below shows that $85.6 \%$ of the 708 responders do voluntary work during these duties.

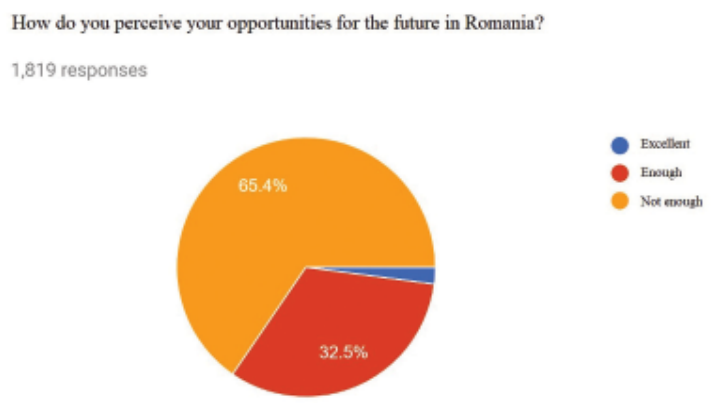

The $3^{\text {rd }}$ question revealed the fact that this practice happens in the majority of the public hospitals in Romania, $89.3 \%$ of the responders saying that in their hospital there are more doctors working on call and some of them are working without being paid.

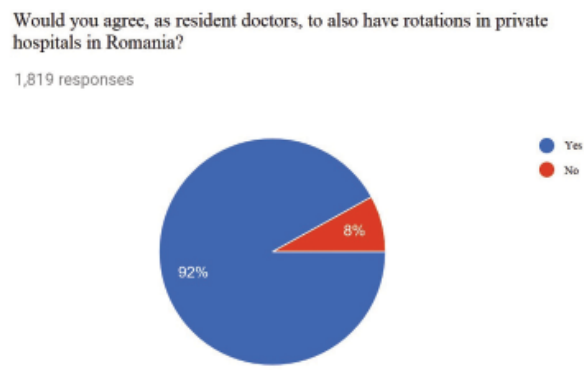


Another issue that was revealed was the fact that for the on-call duty, $86.6 \%$ of the residents didn't even have a contract with the hospital to attest their duty hours. The rest of the responders were probably residents in the $3^{\text {rd }}-6^{\text {th }}$ year of training, working in hospitals that pay for the duty hours. When there is money involved, a contract is mandatory.

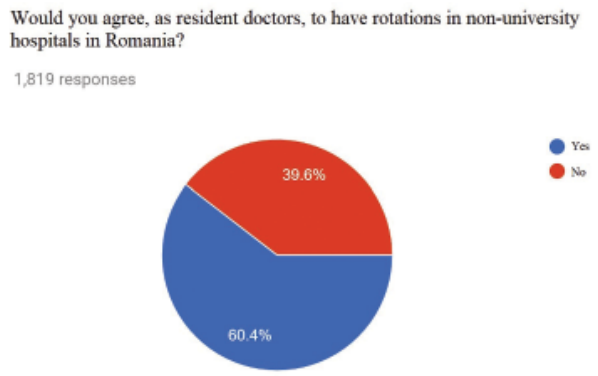

The next question showed the fact that the residents were willing to take part in a protest if the Ministry of Health wouldn't find a solution to pay the first and second year residents for the on call duties. $89.6 \%$ responded that they would participate in such an action if the correct measures would not be taken.

Would you agree, as future resident doctors, to have rotations in health facilities in the rural area?

1.819 responses

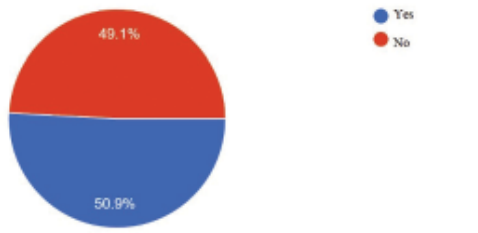

Asked if the on call duties would become optional, $85.1 \%$ of the residents said that they would not do any more voluntary (unpaid) duties. This clearly showed the fact that the residents did not perform these duties because they wanted, but because they were obliged.

How many on call duties do (711 responses) you have per month?
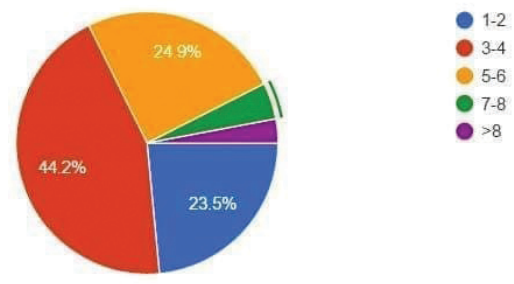
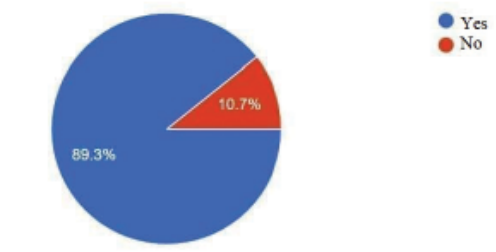

Although currently private hospitals do not prepare residents (these being taught only in public hospitals

After submitting these responses to the Romanian Ministry of Health, a new law was conceived which allowed residents in the first and second year of training to perform paid on call duties, but only having a higher line to watch over them (either a specialist or a consultant).

Although doctors' salaries were raised in 2018 and the migration process decreased, there are still issues to be addressed in the medical system ${ }^{4}$.

A survey conducted in 2019 by the Romanian Federation of Medical Students' Associations (FASMR), on 1819 students from the $5^{\text {th }}$ and $6^{\text {th }}$ years of studies, shows that some of these issues remain and that future doctors are still concerned with their working conditions and their career perspectives in Romania ${ }^{5}$.

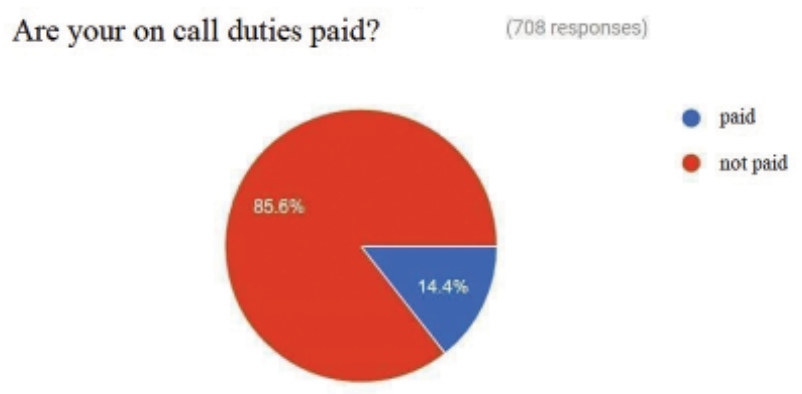

Asked whether they would like to practice in Romania or abroad, $88.1 \%$ of the responders said that they would like to make a career at home. However, $65.4 \%$ of the interviewed realize that they will have difficulties in Romania after finishing the residency and only half of this percentage believes that they will have good

Are there more doctors working on call in each rotation and some of them are not paid?

(709 responses) perspectives in the end. 
Did you sign a contract with your hospital for doing the on call duties?
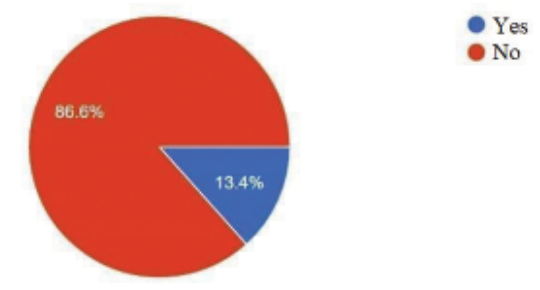

and only by university personnel), $92 \%$ of the future residents responded that they would like to have the possibility of being trained in private hospitals as well. Moreover, $60.4 \%$ of them would accept doing their residency in hospitals which don't have university personnel, even in smaller cities.

Asked whether they would accept part of the residency training to take place in rural medical facilities, only half of the responders (50.9\%) agreed to this idea. This shows that there is some degree of openness from the future doctors to solve the problem of national healthcare coverage, but the results also indicate that more incentives for young doctors are required in order to make rural practice truly appealing.

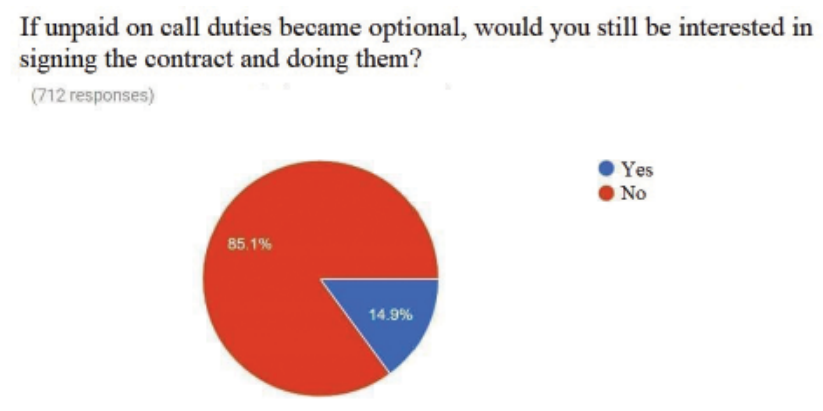

\section{DISCUSSIONS}

Although in some clinics were there was a great need of residents the new law was beneficial, implementing it in most of the hospitals in Romania is a difficult step

\section{References}

1. https://umfcd.ro/comunicat-de-presa-peste-1-460-de-locuriscoase-la-concurs-pentru-admiterea-in-umf-carol-daviladin-bucuresti/

2. http://www.viata-medicala.ro/*articleID_11373-dArt.html

3. https://www.facebook.com/societateamultidisciplinaraamedicilorrezidenti
Would you be willing to participate in a demonstration for your rights in case the Ministry of Health won't provide payment for on call duties?

(714 responses)

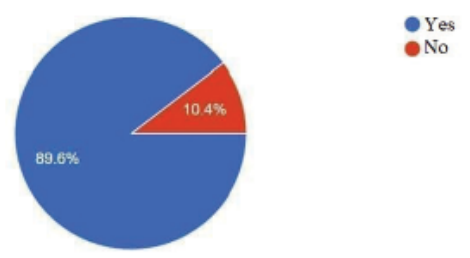

to make, because it is easier to change laws than mentalities.

The implementation process requires the acceptance of the chief of the department and the manager of the hospital; therefore, new efforts need to be made for the residents to gain the right they obtained. The resistance to the new legislation persists because hospital managers do not desire to pay extra for a service which has been done for free for many years. Therefore, many resident doctors are still dissatisfied with the working conditions in Romanian hospitals.

\section{CONCLUSIONS}

There are some improvements over the last 3 years when it comes to salaries and legislation which diminished the massive emigration of the young Romanian doctors. These efforts must be continued, especially when it comes to the working conditions in rural areas, in order for the country to have a strong health system.

The opinion of young doctors, evaluated through different surveys, is the best way to feel the pulse of the health system and their solutions for key problems should be taken into consideration.

Compliance with ethics requirements: The authors declare no conflict of interest regarding this article. The authors declare that all the procedures and experiments of this study respect the ethical standards in the Helsinki Declaration of 1975, as revised in 2008(5), as well as the national law. Informed consent was obtained from all the patients included in the study.

4. https://romanialibera.ro/sanatate/exodul-cadrelor-medicaleun-fenomen-in-remisiune-755612

5. https://issuu.com/teodorblidaru/docs/fasmr-raport-preliminar-rezidentiat 